ISSN 2078-6441. Вісник Львівського університету. Серія географічна. 2013. Випуск 44. С. 356-363. Visnyk of the Lviv University. Series Geography. 2013. Issue 44. P. 356-363.

$631.445 .4(477.54+477.52)$

\author{
митро ихоненко, остянтин овос д, митро вв \\ рківський н ціон льний гр рний університет імені . . окуч єв , \\ n/в омуніст-1, 62483, м. рків, кр їн,
}

икл дено результ ти комплексних польових, л бор торних т експедиційних досліджень, у ході яких вивчено фізико-хімічні, кислотно-лужні, мікробіологічні, мікроморфологічні вл стивості т дин міку лінії з ляг ння к льцію к рбон тів у чорноземних грунт х пост грогенного й грогенного використ ння. оведено, що вплив лісової рослинності н грономічні пок зники чорноземів типових м йже однотипний з дією тр в'яних фітоценозів. ведено теоретичні уз г льнення і з пропонов но теорію еволюції грунтотворного процесу під тр в'яними, штучними лісовими фітоценоз ми, т кож в гроценоз х.

лючові слов : чорнозем, еволюція, пост грогенні й грогенні грунти, елемент рні грунтові процеси, фітоценоз, “ грочорноземи”, “чорноземи лісові”.

роблем еволюції чорноземних грунтів з різного використ ння (лісового, степового, культурного) є особливо в жливою в суч сних умов х проведення земельної реформи в кр їні. ому для р ціон льного використ ння чорноземних грунтів і підвищення їхньої родючості необхідне всебічне вивчення грунтотворного процесу і пізн ння його еволюції з різних умов використ ння ( грогенного т пост грогенного).

ем є одност йності в погляд х дослідників щодо н пряму грунтоутворення чорноземних грунтів пост грогенного використ ння, особливо під лісовими н с дженнями. еякі вчені з зн ч ли про процеси дегр д ції (опідзолюв ння) чорноземних грунтів під лісовими н с дженнями $[4,7]$. нші вв ж ють, що чорноземи під лісом розвив ються 3 особливим процесом грунтоутворення [6, 12, 13, 15, 16], і перекон ні, що дегр д ція не відбув ється. одо орних грунтів, то в н уковій літер турі є неоднозн чне тр ктув ння їхнього розвитку $[1-3,5,8,9,11,14,17]$. зн чені суперечності поглядів спонук ли н с до вивчення еволюції чорноземів під різними фітоценоз ми, щоби прогнозув ти под льші зміни вл стивостей.

ш мет - дослідити з кономірності грогенної і пост грогенної еволюції чорноземів типових у різних екосистем х, виявити головні зміни грономічних х $\mathrm{p}$ ктеристик грунтів і н д ти прогноз їхнього под льшого р ціон льного використ ння.

ля дослідження пост грогенних змін чорноземів типових і розкриття їхніх еволюційних трендів обр но три типові ст ціон ри для івобережного ісостепу кр їни: “ их йлівськ цілин” ( ебединський р-н, умськ обл.), ог нський ст ціон $p$ ( рківський р-н, рківськ обл.) т крип ївський ст ціон $\mathrm{p}$ ( міївський $\mathrm{p}-\mathrm{H}$, рківськ обл.). сі вони розт шов ні в меж х ередньоруської лісостепової провінції ісостепової зони кр їни і є типовими 3 основними пок зник ми природного середовищ .

(C) ихоненко ., овос д ., вв ., 2013 
меж х ст ціон ру “ их йлівськ цілин ” досліджув ли чорноземи типові середньосуглинкові н лес х, що перебув ють у різному (пост грогенному й грогенному) використ нні: бсолютн цілин, кошен цілин (один р з у дв роки), кошений переліг (віком 65 років), лісосмуг (клен віком 65 років), орні землі (використ ння в зон льних сівозмін х пон д 120 років) н полі № 4 польової сівозміни “ теринівк 1".

меж $\mathrm{x}$ ог нського ст ціон ру (дослідне поле $\mathrm{T}$ дендроп рк ім. . . окуч єв ) об'єкт ми досліджень обр но чорноземи типові в жкосуглинкові н лес $\mathrm{x}$, які перебув ють т кож у різному пост грогенному $\mathrm{T}$ грогенному використ нні: орні (пон д 100 років), під перелогом (65 років), під лісосмугою із дуб (65 років), під березою (40 років), сосною (40 років), смерекою (40 років), кошеним перелогом (40 років).

меж х крип ївського ст ціон ру вивч ли природні втоморфні сірі опідзолені грунти пр вого корінного берег , які були природним контролем лісових грунтів.

н літичні дослідження грунтів проводили згідно з з г льноприйнятими методик ми: уміст зг льного гумусу методом . юрін в модифік ції . им ков ( 4289:2004), груповий скл д гумусу - методом ононової- ельчикової ( 31-497058-006-2002); обмінно-поглинуті к тіони $\mathrm{Na}^{+} \mathrm{i}{ }^{+}$визн ч ли н полуменевому фотометрі, ${ }^{2+} \mathrm{i} \mathrm{g}^{2+}-$ комплексометрично, ємність поглин ння грунтів - універс льним методом . $\mathrm{x}$ рчук з сумою обмінно-поглинутих к тіонів; пок зники $\mathrm{p}$ потенціометрично: $\mathrm{p}$ водний, $\mathrm{p}$ сольовий ( $\quad$ ISO 10390:2007); пок зник гідролітичної кислотності - з ппеном ( 26212-91). ля мікроморфологічних досліджень відібр ли проби грунтів (моноліти) непорушеної будови для виготовлення шліфів, які описув ли з допомогою мікроскоп $-15 \quad$ з використ нням бінокуляр -1 . ізні групи мікроорг нізмів ур ховув ли методом широкого мікробіологічного н лізу, висів ючи грунтову суспензію н щільні живильні середовищ (м'ясо-пептоновий г р ( ), крохм льно- мі чний г p ( ), пептоноглюкозний г р ксм н ( ), голодний г p ( ), середовище шбі ( )) ікробіологічний посів проводили з ст нд ртними методик ми. етоди для спостереження й обліку колоній мікроорг нізмів у грунті т скл д середовищ - 3 . вягінцевим.

г льний уміст $і$ груповий скл д гумусу. чорнозем х типових “" их йлівської цілини” уміст з г льного гумусу в бсолютно цілинній ділянці з повідного степу ст новив $10,1 \%$ у ш рі 0-5 cм. глибиною (5-20 см) простежув лося зниження кількості гумусу до 8,5\%, у ш р х 20-40 см - 6,4\%. орнозем кошеної ділянки цілинного степу м в дещо нижчий уміст з г льного гумусу порівняно з грунтом бсолютної цілини (відповідно, до глибин, $-9,6,7,9,6,6 \%$ ). ід деревними н с дженнями (в рі нт лісосмуги) уміст гумусу в ш рі 0-5 см-9,1, з глибиною (5-20 см) відсоток гумусу знижується до 7,5. йнижчий уміст гумусу з фіксов но в чорноземі ріллі $(5,9 \%)$. ш рі 5-20 см уміст гумусу незн чно відрізняється від вищого ш ру. ип гумусу чорноземів типових “" их йлівської цілини” фульв тно-гум тний і гум тний $(:=1,10-2,05)$.

меж $\mathrm{x}$ ог нського ст ціон ру з г льний уміст гумусу в орних чорнозем х $\mathrm{y}$ верхньому горизонті досяг $€ 5,1 \%$, в грунт х кошеного перелогу $-6,6 \%$, перелогу 7,2\%. еревні н с дження зумовлюють кумуляцію гумусу (у верхньому 0-5 см ш рі), \%: під дубом - 7,1, березою - 6,8, смерекою - 5,5, сосною - 5,4. груповим скл дом гумус чорноземів типових ог нського ст ціон ру гум тний ( : >2). 
сірих опідзолених грунт х уміст з г льного гумусу досяг є 4,0\% (0-5 см ш р) т 2,5-2,1\% у глибших ш р х. ип гумусу сірих опідзолених грунтів фульв тно-гум тний ( : $\quad=1,22-1,12)$.

ікроморфологічн $х$ р ктеристик чорноземів типових кр їнського природного степового з повідник “ их йлівськ цілин ”. сім досліджув ним грунт м вл стиві: 1) елемент рн мікробудов досліджених грунтів пл змово-пилув т . міни співвідношення скелетних і пл змових компонентів униз по профілю (до 50 см) не виявлено.

кож нем озн к перегрупув ння компонентів у меж х окремих ш рів. келет предст влений пилув тими ч стк ми, розподілений в грунтовому м тері лі рівномірно; 2) пл зм верхніх гумусових горизонтів гумусово-глинист , ізотропн , ско гульов н , без озн к рухливості, дост тньо однорідн 3 скл дом і просторовим розподілом - нем мікрозон збіднення гумусом і глиною. поверхні скелетних зерен тонкодисперсний м тері л утворює пухкі кут ни різної потужності, що свідчить про відсутність процесів винесення тонкодисперсних компонентів 3 верхньої ч стини профілю; 3) форм гумусу - муль, для якої х р ктерні: перев ж ння мікроформ орг ніки н поч ткових (свіжі й сл бко розкл дені рослинні рештки) і кінцевих (темно-бурий гумус гумінів і світло-бурий морфний гумус) ст діях тр нсформ ції; високий ступінь переробки орг нічних решток педоф уною; 4) висок біогенн т ко гуляційн мікро грегов ність основної м си; 5) перев ж ння серед компонентів мікроскл дення гумусових горизонтів губч стого м тері лу й грег тів, роль не грегов ного м тері лу в орг ніз ції твердої ф зи другорядн ; 6) висок з г льн грегов ність і пористість мікроскл дення; 7) униз по профілю простежується зменшення пористості і деякі зміни співвідношення площ т зн чення порожнин різного походження і морфології. окрем, грегов ні й губч сті мікрозони м ють комп ктніший вигляд порівняно з поверхневим горизонтом. омітною ст є уч сть у мікроструктурі не грегов ного м тері лу. 'являються поритріщини. кі зміни мікроскл дення пов'яз ні зі змін ми в процес х структуроутворення, с ме: зрост нням зн чення фізичних і фізико-хімічних процесів і зменшенням ч стки фіто- і зоогенних; 8) головним чинником формув ння мікроструктури поверхневих горизонтів є біогенне (зоо- т фітогенне) структуроутворення; 9) нем мікроморфологічних озн к опідзоленості грунтів під штучними лісовими н с дженнями.

ислотно-лужні х $р$ ктеристики. ля чорноземів ог нського ст ціон ру $\mathrm{x} p \mathrm{k}$ терною є нейтр льн ре кція грунтового розчину (p водн. $=6,65-7,12)$ у ш рі 0-40 см. ише в н с дженнях сосни т смереки грунтовий розчин сл бкокислий $(6,32)$. бмінн кислотність приблизно н одиницю нижче $\mathrm{p}$ водн. і у в рі нт х ог нського ст ціон ру колив ється в меж х 5,34-6,31: під смерекою - 5,34, сосною - 5,49, дубом - 5,79, березою-5,93, під ріллею і перелог ми р сол. досяг є зн чень 6,19-6,31. орноземи “ их йлівської цілини” м ють пок зники р водн. у меж х 6,77-7,64: під лісосмугою 3 ясеня - 6,77, бсолютною цілиною - 6,85, кошеною цілиною - 7,28, ріллею - 7,42, перелогом - 7,64, тобто грунти м ють нейтр льну ре кцію грунтового розчину.

сірому опідзоленому грунті в меж х гумусово-елюві льного горизонту $p$ водн. 5,56-6,14, p сол. - 4,49-5,03. ідролітичн кислотність у верхніх горизонт х чорноземів ог нського ст ціон ру м є т кі кількісні пок зники: під н с дженнями смереки і дуб - 2,94-3,18, сосни - 3,45, берези - 2,35, у в рі нт х перелогу 0,84-1,78, ріллі - 1,57 мг-екв/100 г грунту. в рі нт х 3 природними лісовими н лог ми (сірі опідзолені) гідролітичн кислотність досяг є 4,54 мг-екв/100 г грунту. чорнозем х “ их йлівської цілини” гідролітичн кислотність змінюв л ся від 0,57 у в рі нті ріллі до 0,84 мг-екв/100 г грунту у в рі нті перелогу. 
кл д обмінно-поглинутих к тіонів у чорнозем х бсолютно-цілинних степів, перелогів, під штучними лісовими ценоз ми відповід ють гумусово- кумулятивному процесу грунтотворення.

ин мік лінії з ляг ння з. зниженням глибини з ляг ння (див. рисунок) з зн чимо, що: під деревними пород ми н весні (з осені через зиму н весні) лінія “з кип ння" з знизил сь н 3,3-6,3 см, в літньо-осінній період н 1,7-2,7 см; у чорнозем х перелогів осінньо-весняний період - н 6,0 см, 3 літньоосінній - н 0,7-1,0 см; в орних чорнозем х - н 4,7 см н весні т н 0,3 см восени; у сірому опідзоленому грунті під дубом - н 15,3 см н весні, і н 1,3 cм - 3 літньоосінній період; отже, 3 приблизно 40-65 років у грунті під н с дженнями сосни, берези т дуб відбулося зниження лінії “з кип ння” н 12-14 см порівняно з орними грунт ми.

\section{Варіанти}

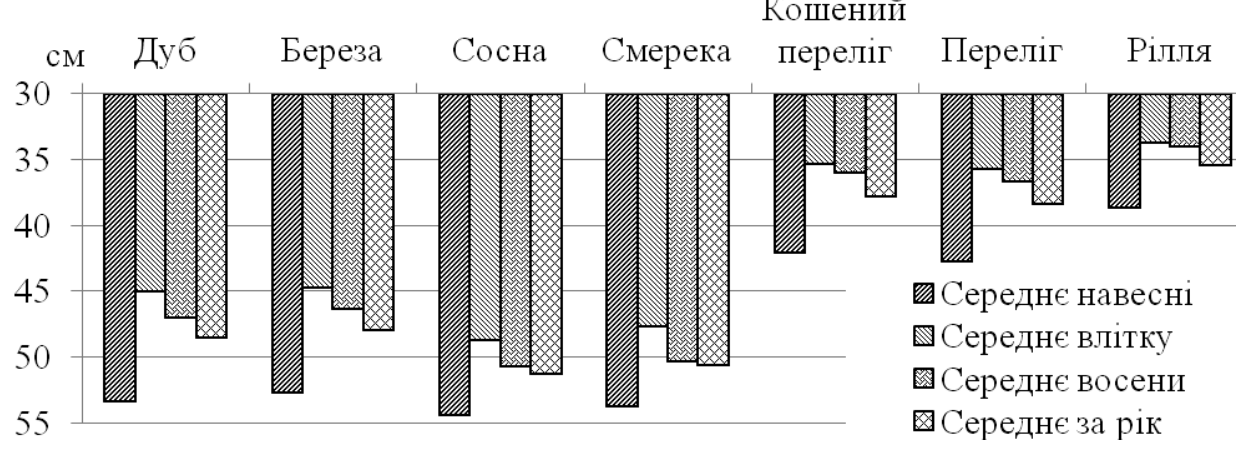

ин мік лінії з ляг ння 3 у чорнозем х типових глибоких в жкосуглинкових н лес х ( ог нський ст ціон р) різного використ ння.

ікробіологічн ктивність чорноземів під різними фітоценоз ми. йбільшу біогенність м ють чорноземи грогенного використ ння - у верхньому генетичному горизонті 0-40 см 6,88, 7,07 млн к. у. з. у 1 г . с. г. (колонієутворюв льних з родків у 1 г бсолютно сухого грунту) н в рі нт х ріллі ог нського ст ціон ру т “ их йлівської цілини". ост грогенне використ ння призводить до суттєвого зниження біогенності у 0-40 см ш рі грунту під усім досліджув ними в рі нт ми, - як під тр в'яними, т к і під деревними фітоценоз ми. ричому в рі нти дуб, берези, кошеного перелогу ог нського ст ціон ру т бсолютної цілини, кошеної цілини, перелогу й лісосмуги колив ються в меж х 5,63-5,91 млн к. у. з. у 1 г . с. г., м йже несуттєво змінюючись 3 в рі нТ ми. йменш біогенність простежується в чорнозем Х пост грогенного використ ння під н с дженнями сосни т смереки ог нського ст ціон ру - відповідно, 4,73, 4,61 млн к. у. з. у 1 г . с. г. сірому опідзоленому грунті під природною дібровою ( крип ївський ст ціон р) біогенність ст новил 5,34 млн к. у. з. у 1 г . с. г.

інтенсивністю мінер ліз ції $\mathrm{K}=1 /$ можн побудув ти т кий ряд: сосн $(1,16)<$ смерек $(1,05)<$ дуб н сірому опідзоленому грунті $(0,96)<$ переліг $(0,87)<$ бсолютн цілин $(0,85)<$ кошен цілин $(0,79)<$ берез $(0,68)<$ дуб т переліг $(0,63)<$ кошений переліг 40 років $(0,59)$. тже, з луження т з ліснення призводить до 
суттєвого зниження біогенності, т кож до посл блення процесів мінер ліз ції, що підтверджено д ними коефіцієнт мінер ліз ції ( $)$.

оефіцієнт мобіліз ції зотного фонду - це співвідношення мікроорг нізмів, що розвив ються н 6 г тих орг нічним і мінер льним зотом середовищ х, до мікроорг нізмів, що розвив ються н бідних середовищ х. iн х р ктеризує н прям змін симіляції зоту в грунт х. им вищий цей коефіцієнт, тим 6 г тший грунт н орг нічний і мінер льний зот. ей коефіцієнт н йнижчий у в рі нт х ріллі, - відповідно, 0,33 і 0,35, т в чорнозем х, що розвив ються під шпильковими деревними пород ми: сосн - 0,24 і смерек - 0,31. в рі нт х під листяними пород ми він у дв -чотири p зи вищий. в рі нт х під тр в'яними фітоценоз ми природного т пост грогенного використ ння він ще вищий і колив ється в меж х 1,35-1,98. е свідчить про високу трофність чорноземів природного т пост грогенного використ ння під тр в'яними фітоценоз ми т в чорнозем х під листяними деревними пород ми: дуб, берез ог нського ст ціон ру т лісосмуг з ясеня ст ціон ру “ их йлівськ цілин”.

лемент рні грунтові процеси чорноземів різних екосистем. гідно з ученням про елемент рні грунтові процеси ( ), кожному типу грунтів, сформов них під впливом мікропроцесів прит м нний певний н бір (комплект) конкретних

орноземи типові в природних умов х формув лися під впливом т ких : 1) повстиноутворення, 2) дерниноутворення, 3) гуміфік ція in situ, 4) гуміфікс ція ( кумуляція) гумусу, 5) біотурб ція, 6) кумуляція к рбон тів к льцію, 7) синтез глинистих мінер лів [14].

грогенне грунтоутворення зумовлює “втр ту” т ких , як повстино- і дерниноутворення цілинних чорноземів, що призводить до змін водного, темпер турного, г зового, окисно-відновного, енергетичних режимів утворених грогенних (орних) грунтів [13]. озорюв ння, обробіток грунту під ч с вирощув ння сільськогоспод рських рослин призводить до перемішув ння грунтової м си верхнього горизонту до 20-30 см, пл нт жною ор нкою - до 65 см, що спричиняє порушення природної будови профілю. ормуються нові, “неспецифічні” [10]. ормується новий профіль грунту під впливом т ких : до природних , які знижуються в дії, дод ються 1) гротурб ція (розорюв ння), 2) біотурб ція, 3) утворення орного ш ру, 4) утворення підорного ш ру, 5) утворення плужної підошви, 6) штучно кумулятивні 3 умов внесення меліор нтів, добрив: орг нічних, мінер льних, 7) гротехнічн дефляція. ід дією цих формується новий профіль грунту: орн., підорн., рк,

к, к. кі грунти потрібно ввести до номенкл турного списку грунтів кр їни під н звою “грочорноземи” [13].

чорнозем х, що формуються під штучними лісовими ценоз ми, т кі: 1) підстилкоутворення, 2) утворення кислої ре кції, 3) гуміфік ція, 4) гуміфікс ція, 5) біотурб ція, 6) профільн дин мік к рбон тів к льцію, 7) синтез і ресинтез глинистих мінер лів. ід дією у лісових штучних ценоз х утворюється т кий профіль: Н о, Н, Н p/k, НP k, P k, що формується у профілі орних чорноземів: орн.,

підорн., H pk, HPk, Pk. тже, під штучними лісовими ценоз ми формується профіль грунту, що м є відмінності порівняно з цілинними й орними чорнозем ми. рім того, змінився один з головних чинників грунтоутворення - рослинність, що вносить суттєві зміни в х р ктер грунтоутворення. ому т кі чорноземи типові пропонуємо виокремити в номенкл турному списку грунтів кр їни під н звою “чорноземи лісові”.

ост грогенний ет п еволюції чорноземів під перелогом поновлює гумусовокумулятивний (дерновий) процес грунтоутворення. 
1) вторинне повстиноутворення, 2) вторинне дерниноутворення, 3) гуміфік ція, 4) гуміфікс ція, 5) біотурб ція, 6) кумуляція 3, 7) синтез і ресинтез глинистих мінер лів, які утворюють т кий профіль: $\mathrm{H} \mathrm{c,} \mathrm{H} \mathrm{d,} \mathrm{H,} \mathrm{Hp} \mathrm{k,} \mathrm{HP} \mathrm{k,} \mathrm{P} \mathrm{k.} \mathrm{рофіль} \mathrm{грунтів}$ перелогу подібний до цілинного н лог, одн к чорноземи цілинні формуються під природною тр в'яною рослинністю н лес х, переліжні- 3 умов с моз рост ння тр в ми н орних чорнозем х.

тже, б г торічні дослідження чорноземів типових івобережного ісостепу кр їни, які розвив ються під різними фітоценоз ми, д ють змогу зробити т кі головні висновки. ліснення орних чорноземів (40-65 років) зумовлює поліпшення всіх пок зників грунтової родючості: зрост є кількість поживних речовин, гумусу, обмінного к льцію, підвищується біогенність і поліпшується структурний ст н грунтової м си, що м йже однотипно з дією тр в'яних ценозів. кро- і мікроморфологічний н ліз будови профілю чорноземів типових під штучними лісовими н с дженнями не виявив озн к опідзолюв ння грунтів, незв ж ючи н сл бке підкислення грунтового розчину.

луження орних чорноземів (переліг - с моз рост ння природними тр в ми) протягом 40-65 років м йже повністю поновлює всі грономічні пок зники до рівня цілинних чорноземів. і гностик грунтогенезу н підст ві комплекту елемент рних грунтових процесів д л змогу виокремити “ грочорноземи” і “чорноземи лісові” у скл ді грунтів кр їни.

\section{СПИСОК ВИКОРИСТАНОЇ ЛІТЕРАТУРИ}

1. $\Omega \epsilon \varepsilon$. . одючість чорноземів звич йних з різних технологій вирощув ння культур / . . л єв, . . онХ , . . ельник // існ. рк. н ц. гр р. ун-ту iм. . . окуч єв . ер. рунтозн вство, грохімія, землеробство, лісове господ рство, екологія грунтів. - 2009. - № 1. - . 85-88.

2. люк . . оль орошения в современной эволюции черноземов типичных евобережной есостепи / . . люк, . . укоб , . . теев // грохимия и почвоведение. - 1990. - ып. 53. - . 57-68.

3. еремеєнко . . волюція т упр вління продуктивністю грунтів олісся : моногр фія / . . еремеєнко. - уцьк : дстир'я, 1997. - 312 с.

4. ильямс . . очвоведение: емледелие с основ ми почвоведения / . . ильямс. - [6-е изд.]. - . : ельхозгиз, 1949. - 472 с.

5. ринченко . . лияние длительной сельскохозяйственной культуры н дин мику гумус , зот и фосфор в почв х юг кр инской / . . ринченко, ин уй- ин // окл. сов. почвоведов к III еждун р. конгрессу в _ . - . : , 1960. - .236-240.

6. онн . . очв к к компонент лесного биогеоценоз / . . онн // сновы лесной биогеоценологии. - . . : ук , 1964. - . 322-410.

7. оржинский . . редв рительный отчет о почвенных и геобот нических исследов ниях 1886 г. в губерниях з нской, м рской, фимской, ермской и ятской / . . оржинский // p. обществ естествоиспыт телей при 3 н. ун-те. - 3 нь : 3 н. ун-т, 1887. - . 16, вып. 6. - . 72.

8. $y x$. . стественно- нтропогенн я эволюция почв (общие 3 кономерности и зон льные особенности) / . . . ух . - . : олос, 2004. - 271 с. 
9. икитин . . волюция дерново-подзолистых почв при окультурив нии : втореф. дис. н соиск ние н учно степени д-р с.-х. н ук: 06.01.03 / . икитин; н-т им. . . окуч ев . - ., 1975. - 43 с.

10. икитин . . культурив ние п хотных почв ечерноземья и регулиров ние их плодородия / . . икитин. - . : гропромизд т, 1986. - 277 с.

11. оско . . нтропогенн еволюція чорноземів / . . оско. - рків : 13 типогр фія, 2006. - 239 с.

12. оде . . енезис почв и современные процессы почвообр зов ния / . . оде. . $\quad$ ук , 1984. $-255 \mathrm{c}$.

13. ихоненко . . грогенне грунтоутворення і кл сифік ція грунтів / . . ихоненко // існ. рк. н ц. гр р. ун-т ім. . . окуч єв . ер. рунтозн вство, грохімія, землеробство, лісове господ рство, екологія грунтів. -2010 . - № 5. - . 5-10.

14. ихоненко . . лемент рні грунтові процеси ( ) при кумулятивному грунтотворенні / . . ихоненко // існ. ім. . . окуч єв . ер. рунтозн вство, грохімія, землеробство, лісове господ рство, екологія грунтів. - 2011. - № 1. . 18-21.

15. $р$ влеєв . . ес к к ф ктор почвообр зов ния / . . р влеєв, . . елов // рунтозн вство. - 2008. - № 3-4. - . 6-26.

16. умин . . лияние лесных полос н почву менной степи / . . умин. оронеж: оммун , 1930. - 40 с.

17. теев . . зменение плодородия чернозем типичного под влиянием орошения и длительного применения р зличных форм зотных удобрений / . . теев, . . оронин // ези докл. съезд почвоведов и грохимиков [“" елиор ция и охр н почв”], (10-14 сентября 1990 г.). - рьков, 1990. - . 85-87.

m ття:н дійшл до ред кцї̈ 07.05.2013

доопр иьов н 31.05 .2013

прийнят до друку 17.06.2013

\title{
EVOLUTION OF CHORNOZEMS OF AGROGENETIC AND POSTAGROGENETIC USING OF LEFT BANK FOREST-STEPPE OF UKRAINE
}

\section{Dmytro Tikhonenko, Kostiantyn Novosad, Dmytro Gavva}

\author{
V. Dokuchaev Kharkiv National Agrarian University, \\ p/o Kommunist-1, UA - 62483, Kharkiv, Ukraine
}

The results of the complex field, laboratory and expeditionary researches of physicochemical (cation-exchange), chemical, acid-alkaline, microbiological, micromorphological properties and dynamics of "effervescence line" in chornozem soils of the postagrogenetic and agrogenetic use, were presented in the thesis. It has been proven that the influence of forest vegetation on the agronomical characteristics of typical chornozems is almost identical to the action of grass fitocenosis. Theoretical generalizations and theory of the soil formation evolution under grass, artificial forest fitocenosis and in agrocenosis were proposed.

Key words: chornozem, evolution, postagrogenesis and agrogenesis, soils, elementary soil processes, fitocenosis, "agrochornozems", black "forestchornozems". 


\section{митрий ихоненко, онст нтин овос д, митрий вв}

рьковский н цион льный гр рный университет имени . . окуч ев , n/о оммунист-1, 62483, г. рьков, кр ин

зложено результ ты комплексных полевых, л бор торных и экспедиционных исследов ний, в ходе которых изучено физико-химические, кислотно-щелочные, микробиологические, микроморфологические свойств и дин мику линии з лег ния к льция к рбон тов в черноземных почв х пост грогенного и грогенного использов ния. ок 3 но, что влияние лесной p стительности н грономические пок з тели черноземов типичных почти однотипны с действием тр вяных фитоценозов. риведено теоретические обобщения и предложено теорию эволюции почвообр зов тельного процесс под тр вяными, искусственными лесными фитоцено3 ми, т кже в гроценоз х.

лючевые слов : чернозем, эволюция, пост грогенные и грогенные почвы, элемент рные почвенные процессы, фитоценоз, “ грочерноземы”, “черноземы лесные”. 